\title{
INFLUÊNCIA DA COBERTURA MORTA NO COMPORTAMENTO DO HERBICIDA SULFENTRAZONE ${ }^{1}$
}

\author{
BENEDITO N. RODRIGUES ${ }^{2}$, JOÃO DE LIMA ${ }^{3}$, INÊS F. UBUKATA YADA ${ }^{4}$ e DONIZETI A. FORNAROLLI ${ }^{5}$
}

\section{RESUMO}

O objetivo deste trabalho foi avaliar o comportamento de sulfentrazone em préemergência no sistema de plantio direto. O experimento foi conduzido na safra 1996/97, na sede do IAPAR Londrina-PR, utilizando-se palha de aveia-preta como cobertura morta. $\mathrm{O}$ delineamento foi o de blocos ao acaso com parcelas subdivididas e quatro repetições. Os tratamentos nas parcelas foram as quantidades de palha: zero, seis e 12 t/ha de matéria seca e nas subparcelas as doses de sulfentrazone: zero, 300, 600,900 e $1200 \mathrm{~g} / \mathrm{ha}$ i.a. A cultura de verão foi a de soja, cv. BR-4. O herbicida foi aplicado com pulverizador de precisão $\left(\mathrm{CO}_{2}\right)$ munido com barra de $3 \mathrm{~m}$ e seis bicos 80.02, vazão de 200 1/ha e pressão de $35 \mathrm{lb} / \mathrm{pol}^{2}$. Vinte e quatro horas após a aplicação do produto, foi feita uma irrigação de $20 \mathrm{~mm}$ para forçar a lixiviação do herbicida da palha para o solo. Antes e após a irrigação, foram feitas amostragens de solo e da palha para serem submetidas a análise de resíduos por cromatografia. Parte desse solo amostrado, foi utilizado em bioensaios, utilizando-se sorgo forrageiro como planta-teste. Pelos resultados observados no campo, nos bioensaios (toxicidade no sorgo) e pelos resultados das análises cromatográficas de resíduos na palha e no solo, concluiu-se que o sulfentrazone atingiu o solo, sendo lixiviado inclusive para camadas superiores a $10 \mathrm{~cm}$ de profundidade.

Palavras chave: Plantio direto, cobertura morta, cromatografia, sulfentrazone, resíduo.

\section{ABSTRACT \\ Influence of the mulch on the behavior of sulfentrazone}

The plant residues are the main part of the no-tillage system. Although these soil covers reduce weed population density, they might intercept herbicides when applied on the mulch. Field experiment, bioassays and chromatografic analysis were made using sulfentrazone at the rates: zero, 300, 600, 900 and 1200 g.a.i/ha applied on 6000 and $12000 \mathrm{~kg} / \mathrm{ha}$ of oat residues and on soil without mulch. Soil and straw samples were collected immediately after sulfentrazone application. Twenty-four hours after sulfentrazone application the field was irrigated and more samples were collected for bioassays and chromatografics analysis. The results showed that the weed-crop competition was reduced under mulch conditions. The weed population was formed by Brachiaria plantaginea only. Sulfentrazone leached more than $10 \mathrm{~cm}$ deep in the soil surface after irrigation.

Key words: No-till; mulch; sulfentrazone; residue.

\footnotetext{
${ }^{1}$ Recebido para publicação em 16/11/98 e na forma revisada em 11/03/99.

${ }^{2} \mathrm{Eng}^{\mathrm{O}} \mathrm{Agr}^{\mathrm{o}}$, PhD, Pesquisador, Instituto Agronômico do Paraná-IAPAR. C.P. 481, CEP: 86001 -970, Londrina/PR.

${ }^{3}$ Eng $^{\circ}$ Químico, MSc, Pesquisador, Instituto Agronômico do Paraná-IAPAR. C.P. 481, CEP: 86001-970, Londrina/PR.

${ }_{5}^{4}$ Eng $^{\mathrm{a}} \mathrm{Agr}^{\mathrm{a}}$, MSc, Pesquisadora, Instituto Agronômico do Paraná-IAPAR. C.P. 481, CEP: 86001-970, Londrina/PR.

5 Aluno de Pós-Graduação. Universidade Estadual de Londrina. Londrina/PR.
} 


\section{INTRODUÇÃO}

O sistema de plantio direto na palha continua sendo um dos mais importantes que se conhece, tanto sob o ponto de vista de controle da erosão como de controle de plantas daninhas (Almeida, 1988).

Apesar de ser um sistema completamente diferente do convencional, os herbicidas continuam sendo recomendados nas mesmas doses em ambos os casos, não se levando em conta os inúmeros fatores que podem interferir na sua eficiência agronômica, quando aplicados sobre palhadas (Rodrigues \& Almeida, 1998).

Em experimentos anteriores, verificou-se que o herbicida atrazine é praticamente lixiviado da palha para o solo com chuva de $20 \mathrm{~mm}$ que ocorram 24 horas após a aplicação do mesmo (Rodrigues \& Almeida, 1986; Fornarolli, 1997). Trabalhos realizados por Rodrigues (1993) e por Rodrigues et al. (1998) mostraram que o imazaquin possui características semelhantes às do atrazine, sendo bem lixiviado da palha para o solo, com boas perspectivas de uso em plantio direto. $\mathrm{O}$ mesmo não pode ser dito em relação a alguns produtos, tais com alachlor, acetochlor e metolachlor (Strek \& Weber, 1982 ; Banks \& Robinson, 1986), oryzalin (Banks \& Robinson, 1984), e metribuzin (Banks \& Robinson, 1982). Verificou-se também, através de cromatografia gasosa, que $o$ herbicida trifluralin não foi detectado nem na palha nem no solo, após chuva com essa mesma intensidade, nesse mesmo espaço de tempo (Rodrigues et al. 1997).

Dando sequência a essa linha de pesquisa, delineou-se o presente trabalho, cujo objetivo foi estudar o comportamento do herbicida sulfentrazone, quando aplicado sobre cobertura morta de aveia preta, no sistema de plantio direto.

\section{MATERIAL E MÉTODOS}

$\mathrm{O}$ experimento foi realizado em condições de campo e em "telado" na Estação Experimental do IAPAR em Londrina, PR, que possui as seguintes características: clima Cfa da escala de Köeppen, solo tipo Latossolo Roxo distrófico, com horizonte A moderado, de textura argilosa ( $81 \%$ de argila, $8 \%$ de silte e $11 \%$ de areia), fase tropical perenifolia e relevo suave ondulado.

Foi adotado o esquema de blocos ao acaso, com parcelas subdivididas, com quatro repetições. Os tratamentos principais, em número de três, foram constituídos pelas seguintes quantidades de cobertura morta: zero, seis e doze t/ha de matéria seca de palha de aveia preta. Os tratamentos secundários, em número de cinco, foram constituídos pelas seguintes doses de sulfentrazone (Boral, 500 g/l): 0, 300, 600, 900 e $1200 \mathrm{~kg} /$ ha i.a. Os dados obtidos foram submetidos a análise da variância, utilizando-se o desdobramento de graus de liberdade para se estudar a regressão polinomial, tanto para níveis de cobertura morta como para as doses de herbicida. As subparcelas, constituídas pelas doses de herbicida, tiveram as seguintes dimensões: área total $=3 \times 7=21 \mathrm{~m}^{2}$; área útil= $2 \times 5=10 \mathrm{~m}^{2}$. Lateralmente a cada subparcela, foram deixadas faixas com $1 \mathrm{~m}$ de largura, não tratadas, que foram utilizadas como termo de comparação nas avaliações visuais, além de proporcionarem maior isolamento a cada subparcela. Nas cabeceiras das parcelas foram deixados arruamentos com 1,0 m de largura para trânsito dentro do experimento.

Após a aplicação do herbicida dessecante glyphosate $(0,54 \mathrm{~kg} / \mathrm{ha}$ i.a. $)$ na cultura de inverno (aveia), foi feita a "rolagem" (passada de "rolofaca"). Em seguida o experimento foi estaqueado e as parcelas foram numeradas. Nas parcelas sem cobertura morta, a palha foi cortada rente ao solo com tesoura manual e em seguida, através de amostragens, foi obtido o peso da matéria seca de palha (6 t/ha). Todo esse material foi distribuído nas parcelas sem corte de palha, formando, portanto, as parcelas com $12 \mathrm{t} / \mathrm{ha}$ de palha. A seguir foi semeada a soja cv BR 4 no sistema de plantio direto, ao espaçamento de $50 \mathrm{~cm}$ entre linhas.

Após a semeadura realizada dia 29/10/96, foi aplicado, em pré-emergência, o herbicida 
sulfentrazone. A aplicação foi feita com pulverizador de pressão constante $\left(\mathrm{CO}_{2}\right)$, munido com barra de seis bicos "Teejet Flat Spray" 80.02, distanciados $50 \mathrm{~cm}$ entre si cobrindo uma faixa de $3 \mathrm{~m}$, vazão de 200 1/ha. Vinte e quatro horas após a aplicação, o experimento foi irrigado, recebendo $20 \mathrm{~mm}$ de água por aspersão. A finalidade dessa irrigação foi forçar a lixiviação do herbicida da palha para o solo.

Imediatamente após a aplicação, e também após a irrigação, foram coletadas num quadrado de $20 \times 20 \mathrm{~cm}$, amostras de palha e de solo, este nas profundidades de 0 a $5 \mathrm{~cm}$ e 5 a $10 \mathrm{~cm}$. Parte das amostras de solo foram armazenadas em sacos plásticos, a $-18^{\circ} \mathrm{C}$, até o momento de serem analisadas no laboratório e as outras partes foram colocadas em vasos plásticos, devidamente identificados, e levados para "telado" onde foram feitos bioensaios. As palhas amostradas também foram igualmente identificadas e estocadas a $18^{\circ} \mathrm{C}$, para serem analisadas posteriormente e quantificados os resíduos do herbicida.

As quantificações analíticas dos resíduos de sulfentrazone foram feitas no Laboratório de Ecofisiologia do IAPAR, através das técnicas de cromatografia de fase gasosa (GC) conforme métodos descritos por Thier \& Zeumer (1987).
Nos bioensaios, foi utilizado o sorgo forrageiro como planta-teste para indicar a presença do sulfentrazone no solo. Nos bioensaios foram feitas medições de altura e peso da matéria seca da parte aérea do sorgo aos 20 dias após a semeadura (DAS).

$\mathrm{O}$ ensaio de campo teve as seguintes avaliações: a) toxicidade na soja (visual $0-100 \%$ ) aos 15 e 50 dias após a aplicação do sulfentrazone (DAA); b) controle de $B$. plantaginea, única espécie de planta daninha presente no experimento (visual 0-100\%) aos 15 e $50 \mathrm{DAA}$; c) produção de grãos de soja (kg/ha).

\section{RESULTADOS E DISCUSSÃO}

O sulfentrazone provocou sintomas de toxicidade na soja, caracterizados principalmente por redução de altura e clorose. Os valores relativos à toxicidade na soja (escala 0-100\%), podem ser observados na Figura 1. Mesmo aos 50 dias após a aplicação (DAA), os sintomas mostravam-se evidentes, sem grandes diferenças entre os tratamentos, cujos valores estão representados na Figura 2. O produto provoca ruptura das membranas celulares, conforme descrito por Rodrigues \& Almeida (1998), causando necrose nas plantas que emergem.

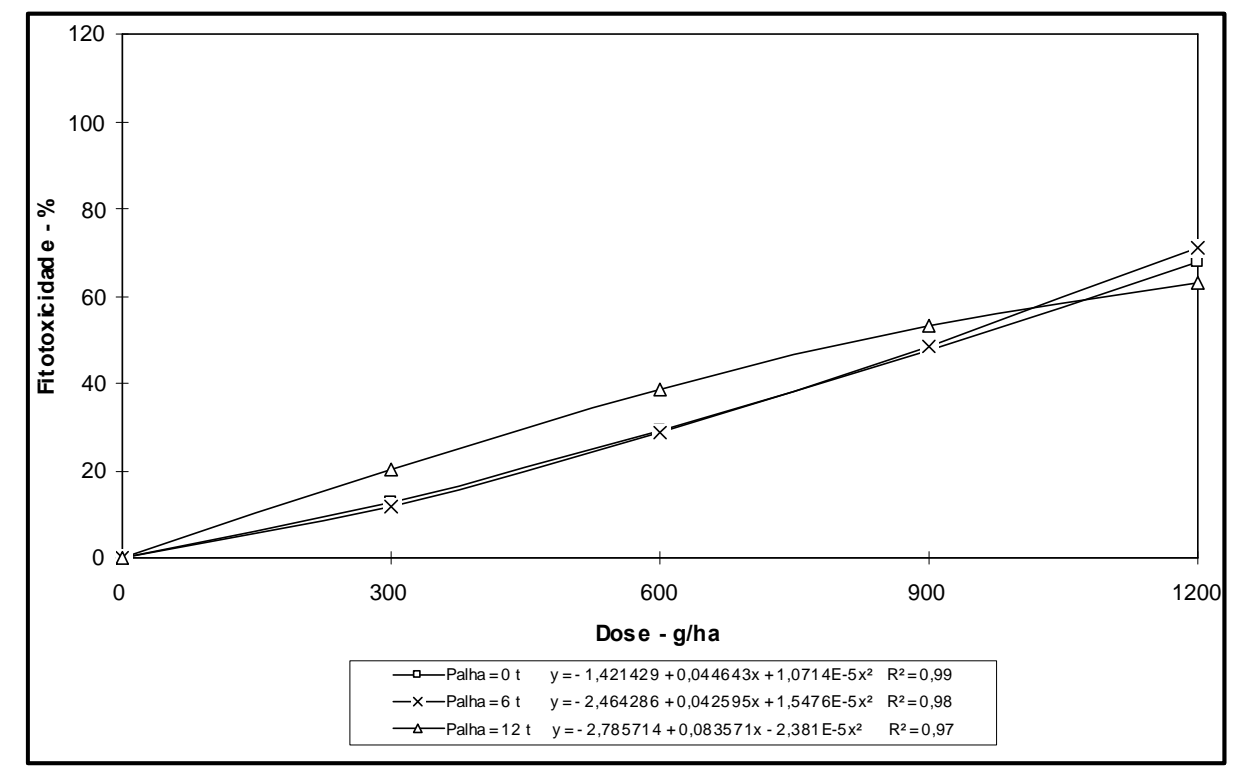

FIGURA 1. Influência da quantidade de palha e da dose de sulfentrazone na fitotoxicidade do produto na soja aos 15 dias após a aplicação. 


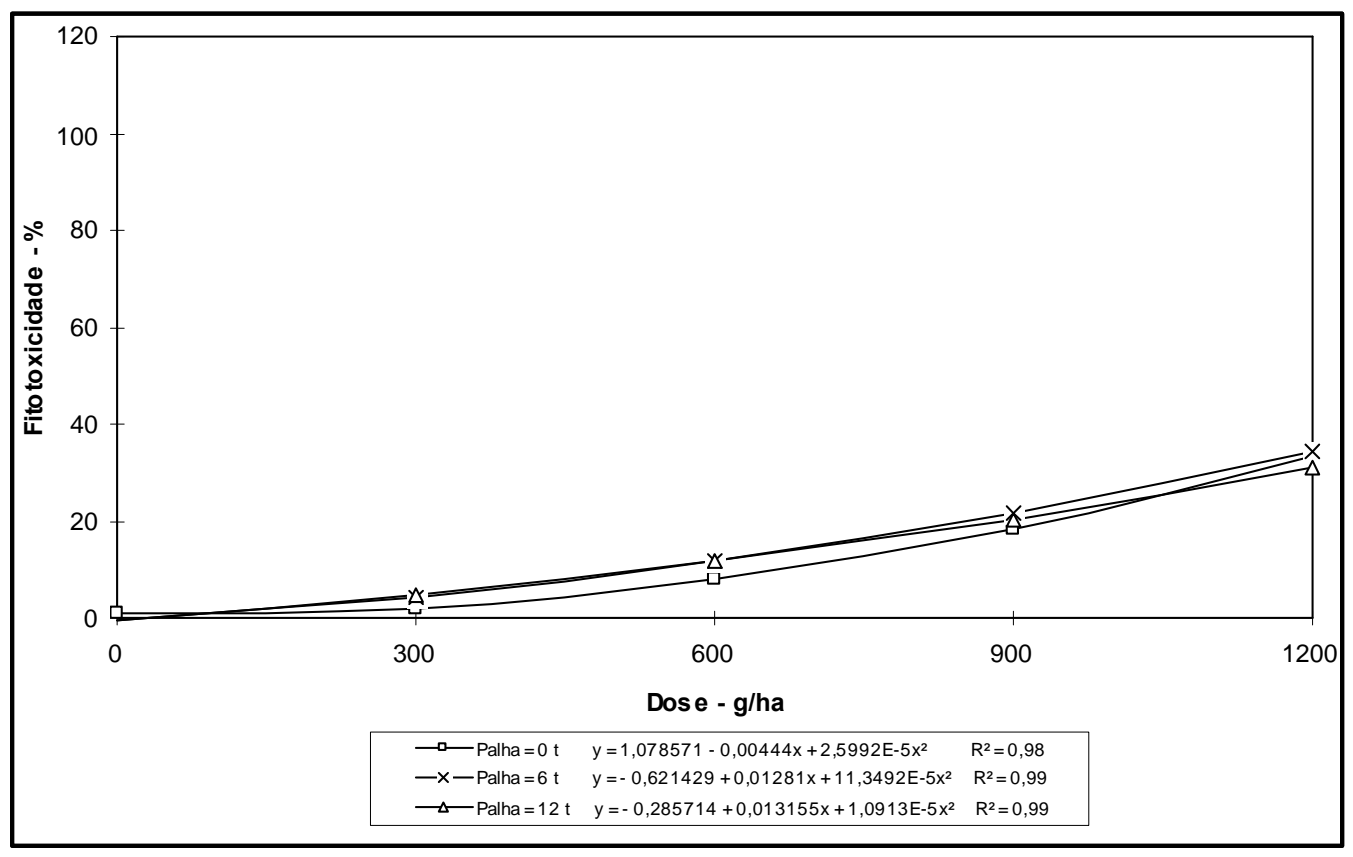

FIGURA 2. Influência da quantidade de palha e da dose de sulfentrazone na fitotoxicidade do produto na soja aos 50 dias após a aplicação.

Em relação ao controle da $B$. plantaginea, única espécie de planta daninha presente no experimento, verificou-se que nas parcelas com palha, mesmo sem aplicação do sulfentrazone, o controle era praticamente total, aos 15 DAA (Figura 3). Essa situação se manteve aos 50 DAA (Figura 4). Observa-se que, nas parcelas sem palha, houve necessidade da aplicação da dose recomendada ( $600 \mathrm{~g} / \mathrm{ha})$, para que o controle fosse semelhante ao obtido com palha e sem herbicida. Resultados semelhantes foram obtidos por Fornarolli (1997) com atrazine e Rodrigues et al (1998) com imazaquin.

Com a decomposição da palha da aveia, no entanto, houve reinfestação do terreno ao longo do tempo. Com isso, ocorreu redução na produção dos tratamentos sem herbicida (Figura 5). As maiores produções foram obtidas com as doses 600 e $900 \mathrm{~g} / \mathrm{ha}$ de sulfentrazone, independentemente da quantidade de palha. $\mathrm{O}$ dobro da dose (1200 g/ha) provocou redução na produção da soja. Isso indica que, mesmo nessas quantidades de palha utilizadas (6 e 12 t/ha M.S.), o herbicida não pode ser dispensado.

Nos bioensaios realizados, observou-se que, mesmo antes da irrigação, houve redução na altura do sorgo com o aumento da dose do sulfentrazone. Essa redução foi mais drástica, como era de se esperar, nos tratamentos sem cobertura morta (Figuras 6 e 7). A redução de altura foi mais evidente em vasos com solos retirados de $0-5 \mathrm{~cm}$ do que de $5-10 \mathrm{~cm}$ de profundidade. O reflexo dessa redução de altura ficou evidenciado na redução do peso da matéria seca da parte aérea do sorgo forrageiro, o que pode ser observado nas Figuras 8 e 9. Isso demonstra que, mesmo antes da irrigação, parte do produto conseguiu atingir o solo, em todos os tratamentos. Após a irrigação, a redução de altura foi mais acentuada ainda, não havendo praticamente diferença entre os tratamentos (Figuras 10 e 11), o que ficou também evidente em relação ao peso da matéria seca do sorgo (Figuras $12 \mathrm{e} 13)$, em ambas as profundidades do solo. 


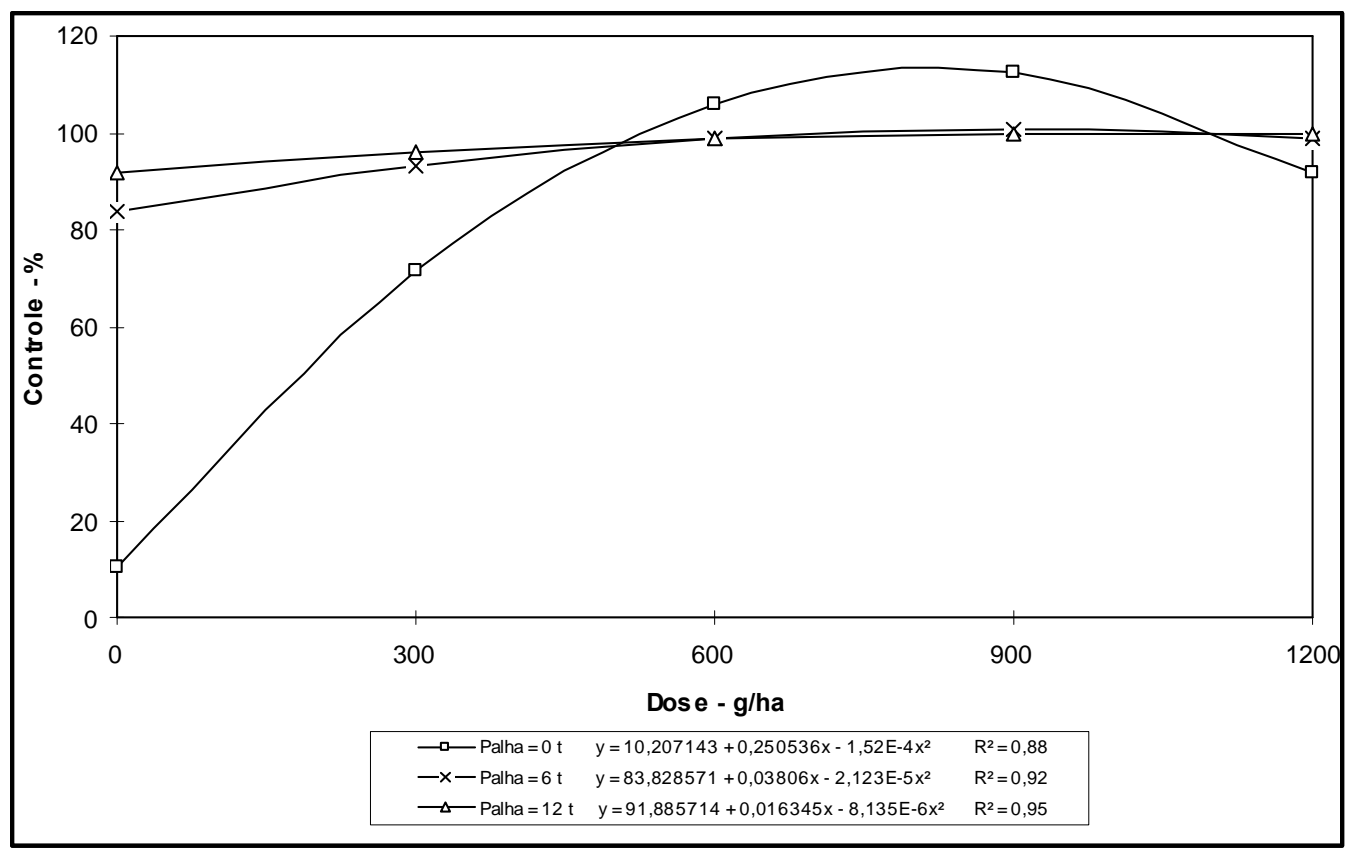

FIGURA 3. Influência da quantidade de palha e da dose de sulfentrazone na porcentagem de controle de B. plantaginea aos 15 dias após a aplicação.

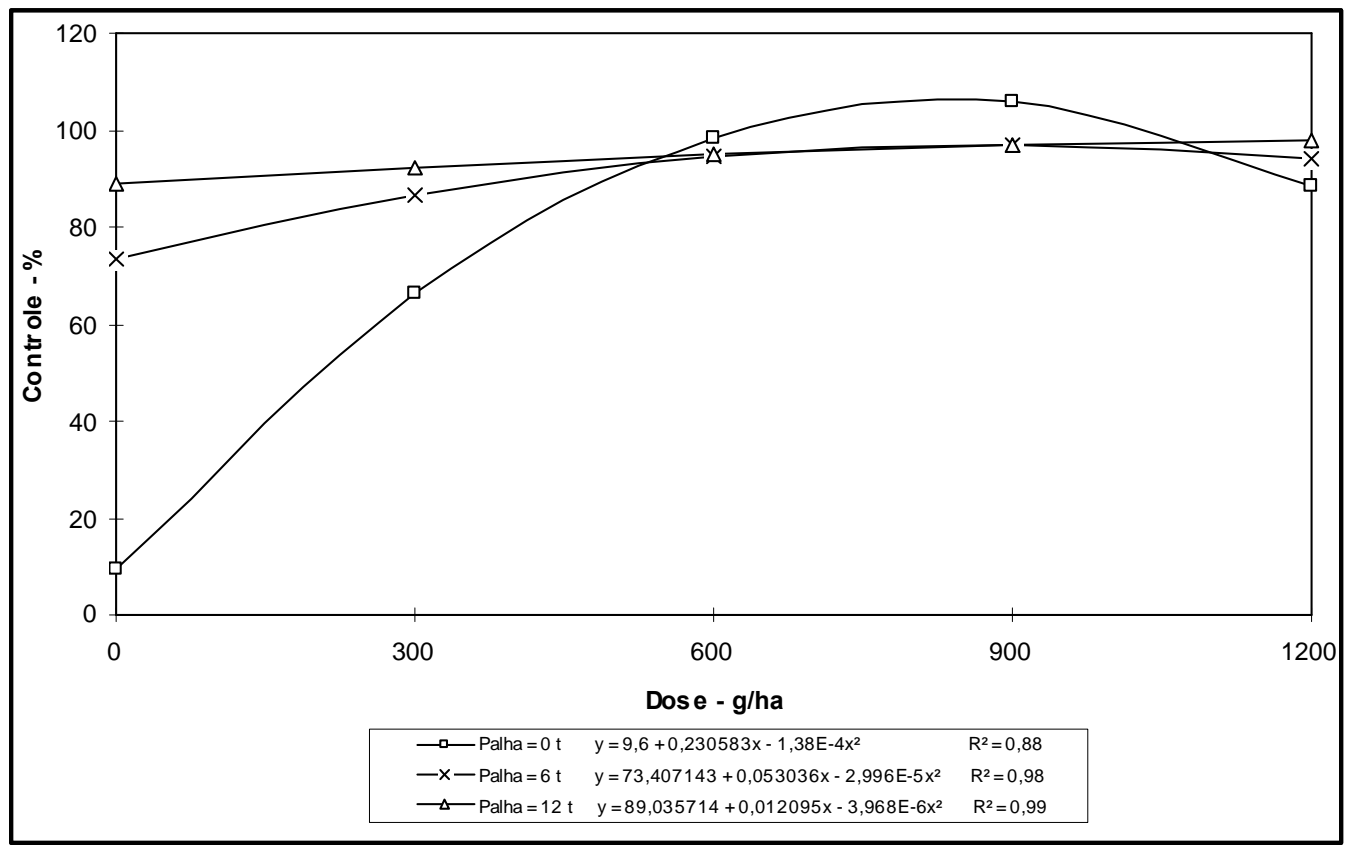

FIGURA 4. Influência da quantidade de palha e da dose de sulfentrazone na porcentagem de controle de B. plantaginea aos 50 dias após a aplicação. 


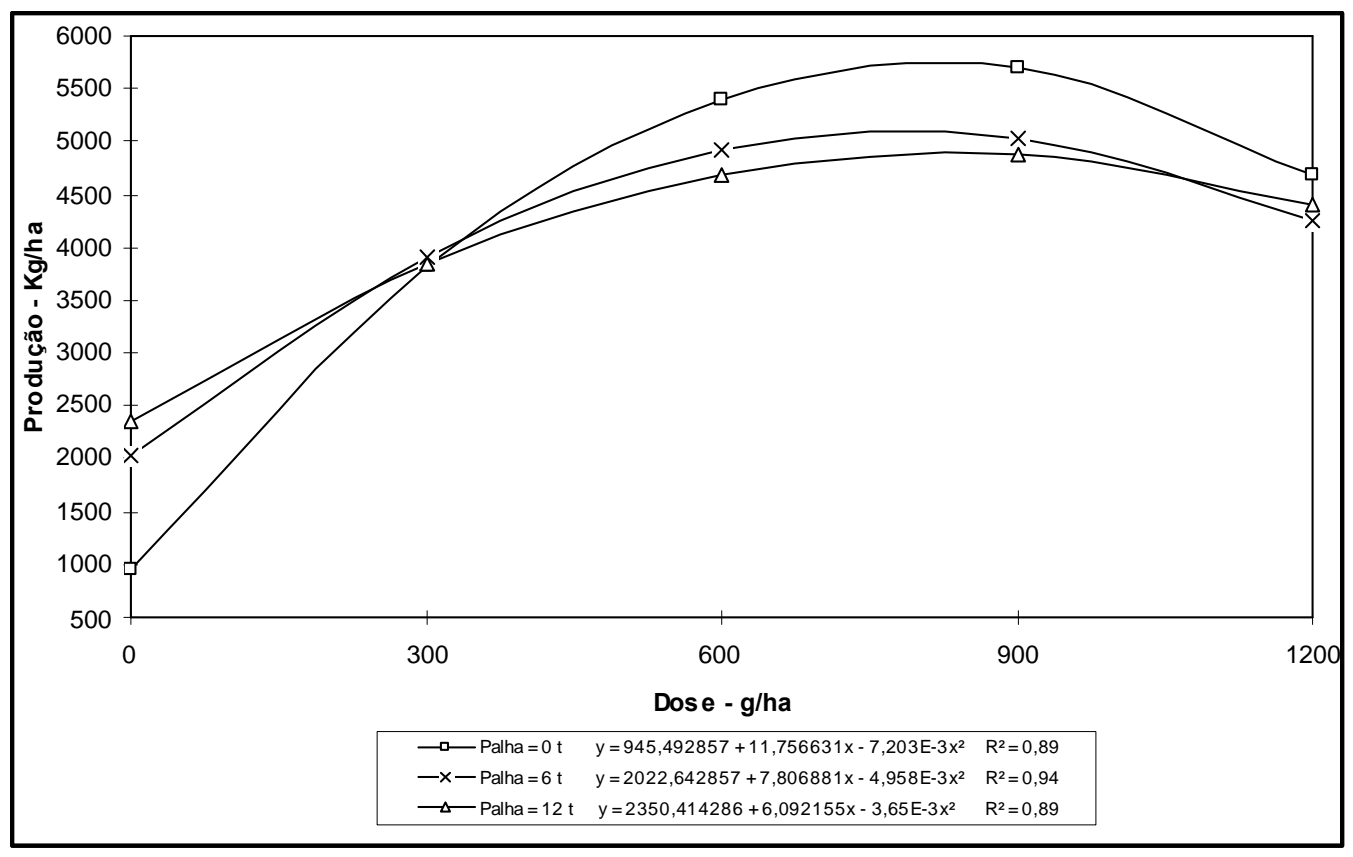

FIGURA 5. Influência da quantidade de palha e da dose de sulfentrazone na produção de soja.

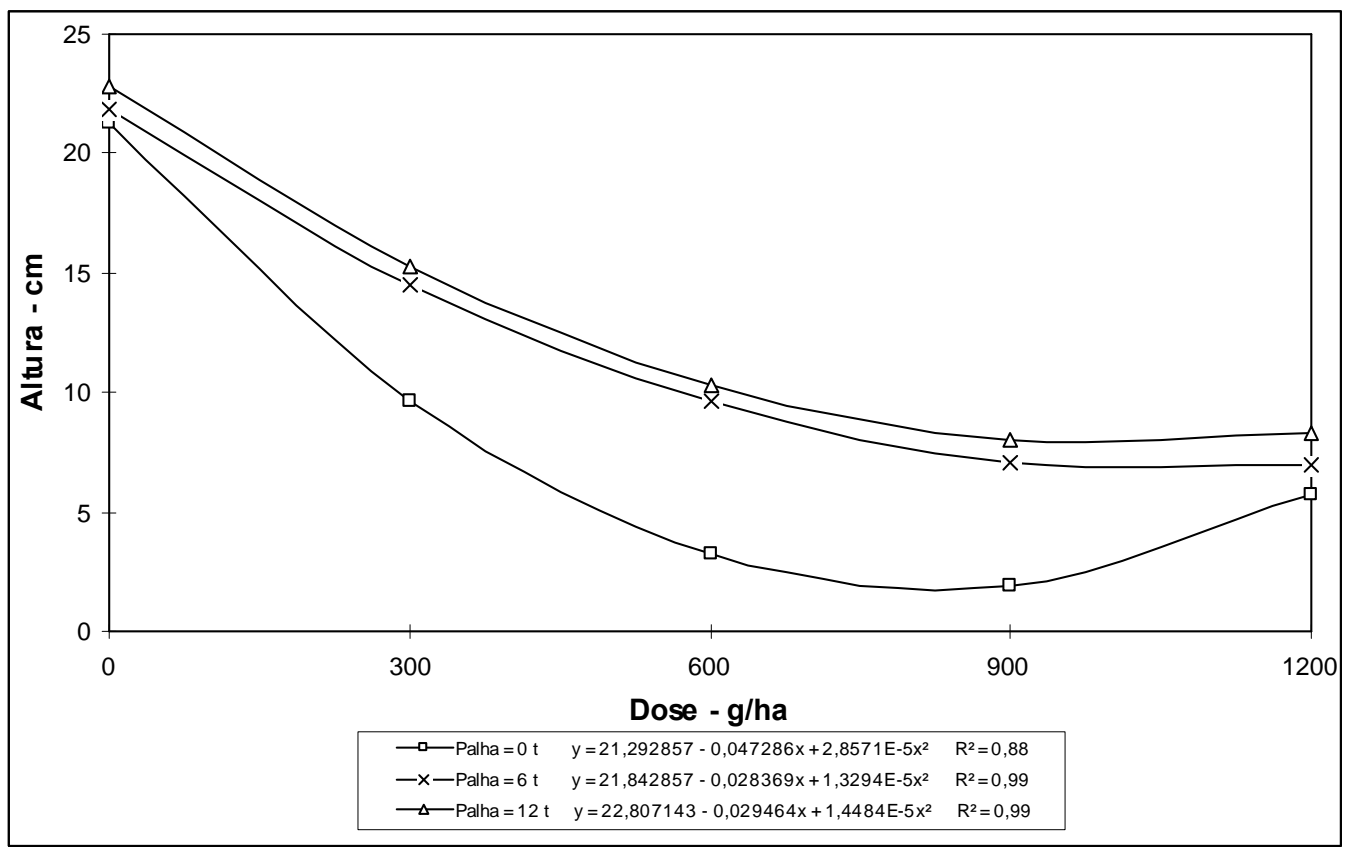

FIGURA 6. Influência da quantidade de palha e da dose de sulfentrazone na altura do sorgo aos 20 dias após a semeadura, em solo retirado na profundidade de 0 a $5 \mathrm{~cm}$, antes da irrigação. 


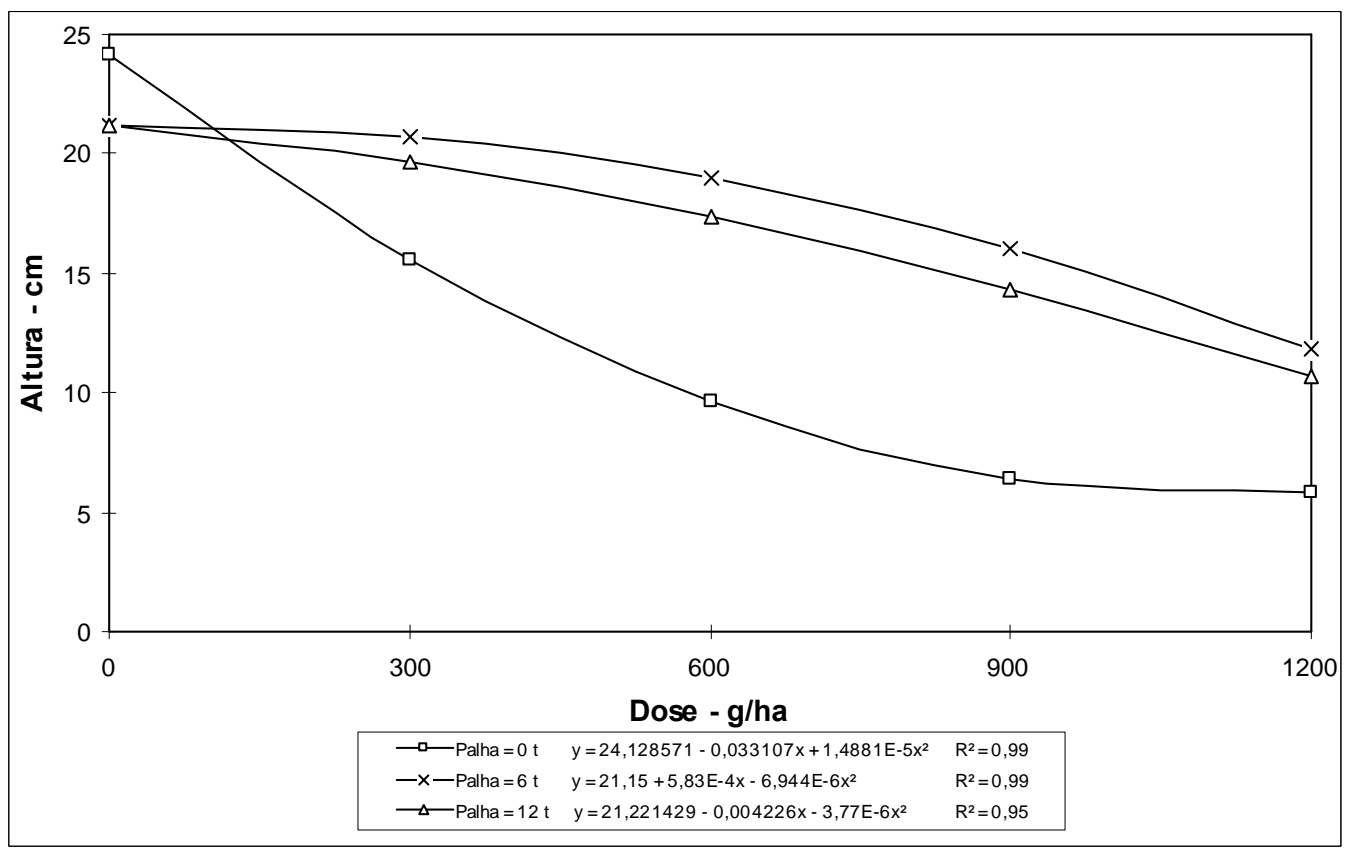

FIGURA 7. Influência da quantidade de palha e da dose de sulfentrazone na altura do sorgo aos 20 dias após a semeadura, em solo retirado na profundidade de 5 a $10 \mathrm{~cm}$, antes da irrigação.

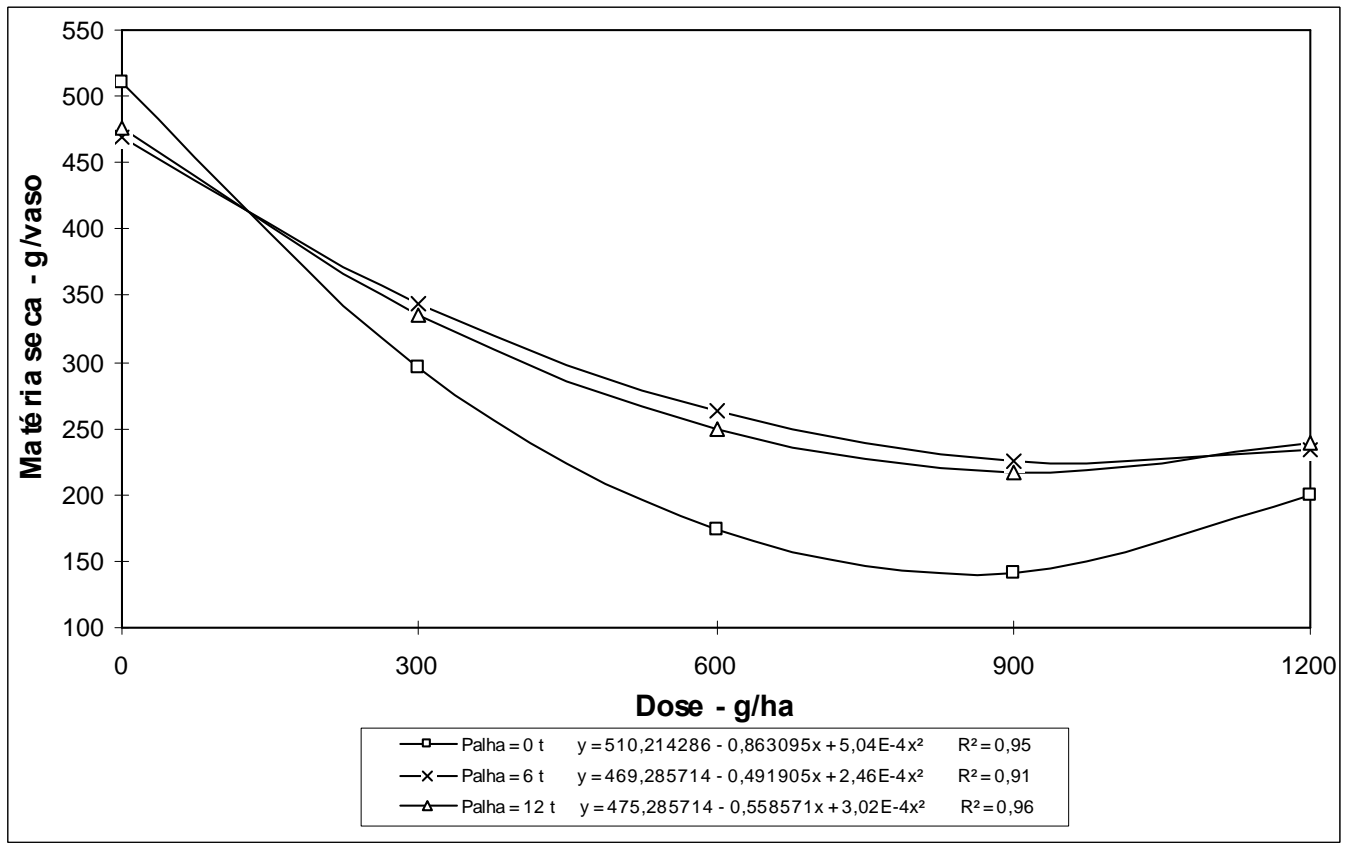

FIGURA 8. Influência da quantidade de palha e da dose de sulfentrazone na produção de matéria seca da parte aérea do sorgo forrageiro aos 20 dias após a semeadura, em solo retirado na profundidade de 0 a $5 \mathrm{~cm}$, antes da irrigação. 


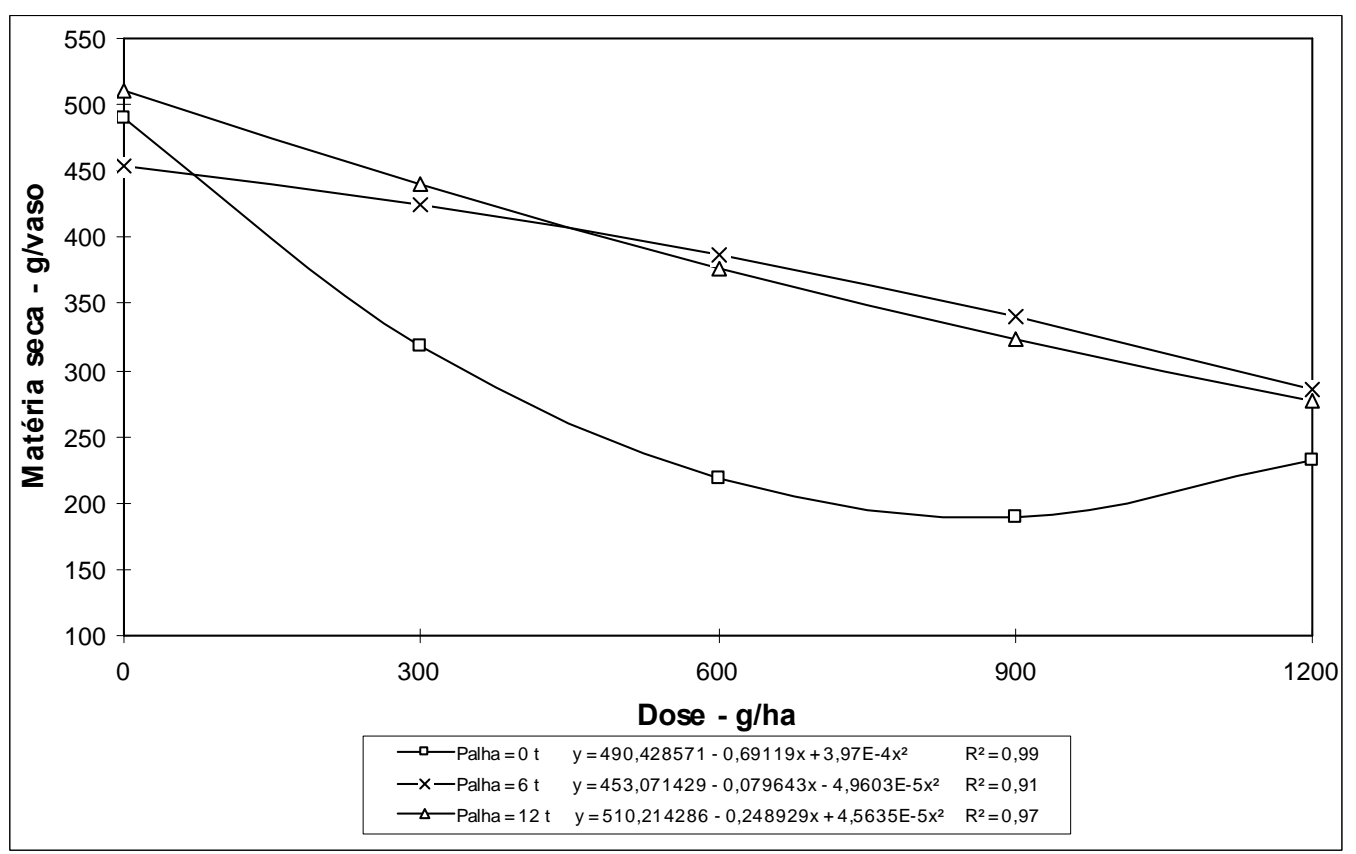

FIGURA 9. Influência da quantidade de palha e da dose de sulfentrazone na produção de matéria seca da parte aérea do sorgo forrageiro aos 20 dias após a semeadura, em solo retirado na profundidade de 5 a $10 \mathrm{~cm}$, antes da irrigação.

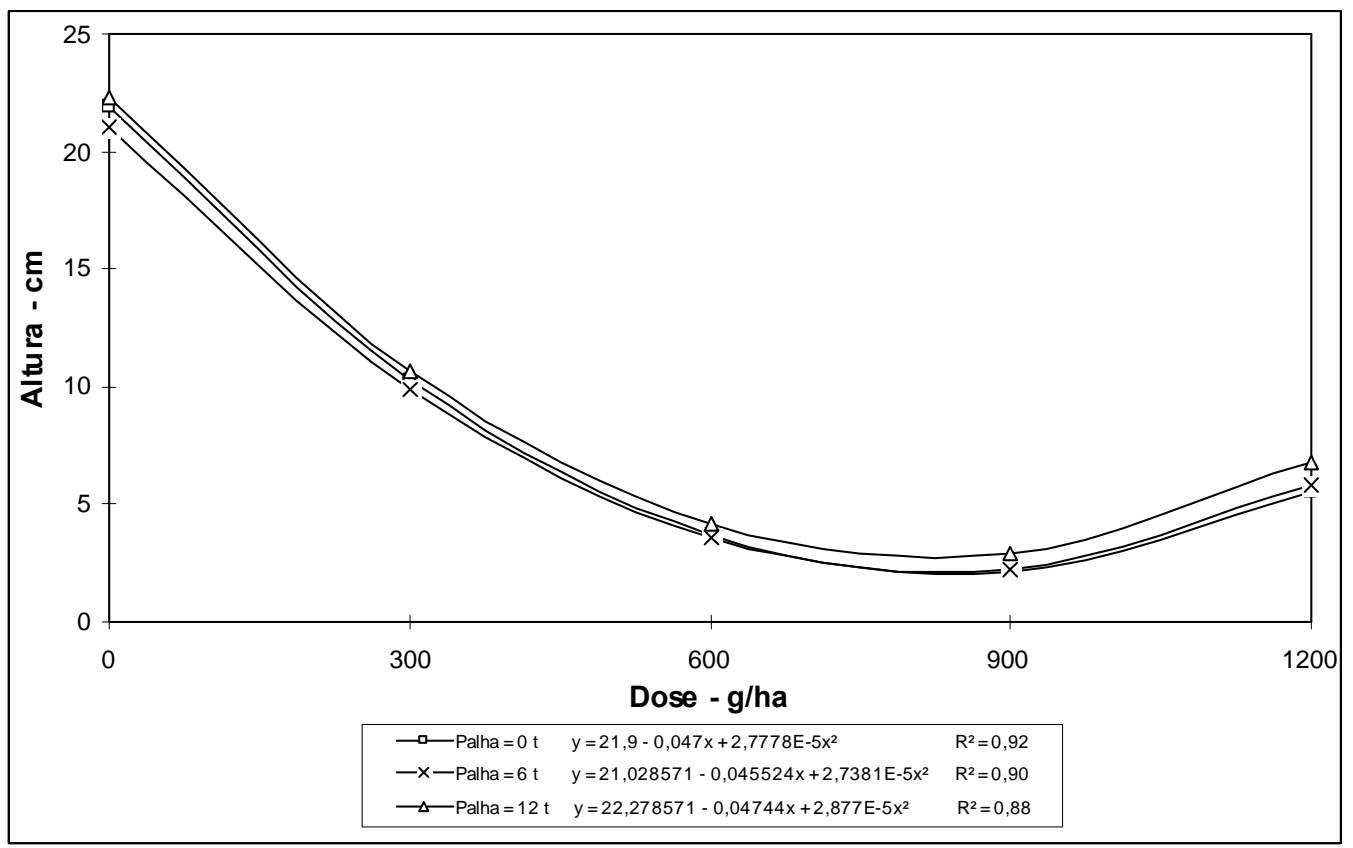

FIGURA 10. Influência da quantidade de palha e da dose de sulfentrazone na altura do sorgo aos 20 dias após a semeadura, em solo retirado na profundidade de 0 a $5 \mathrm{~cm}$, depois da irrigação. 


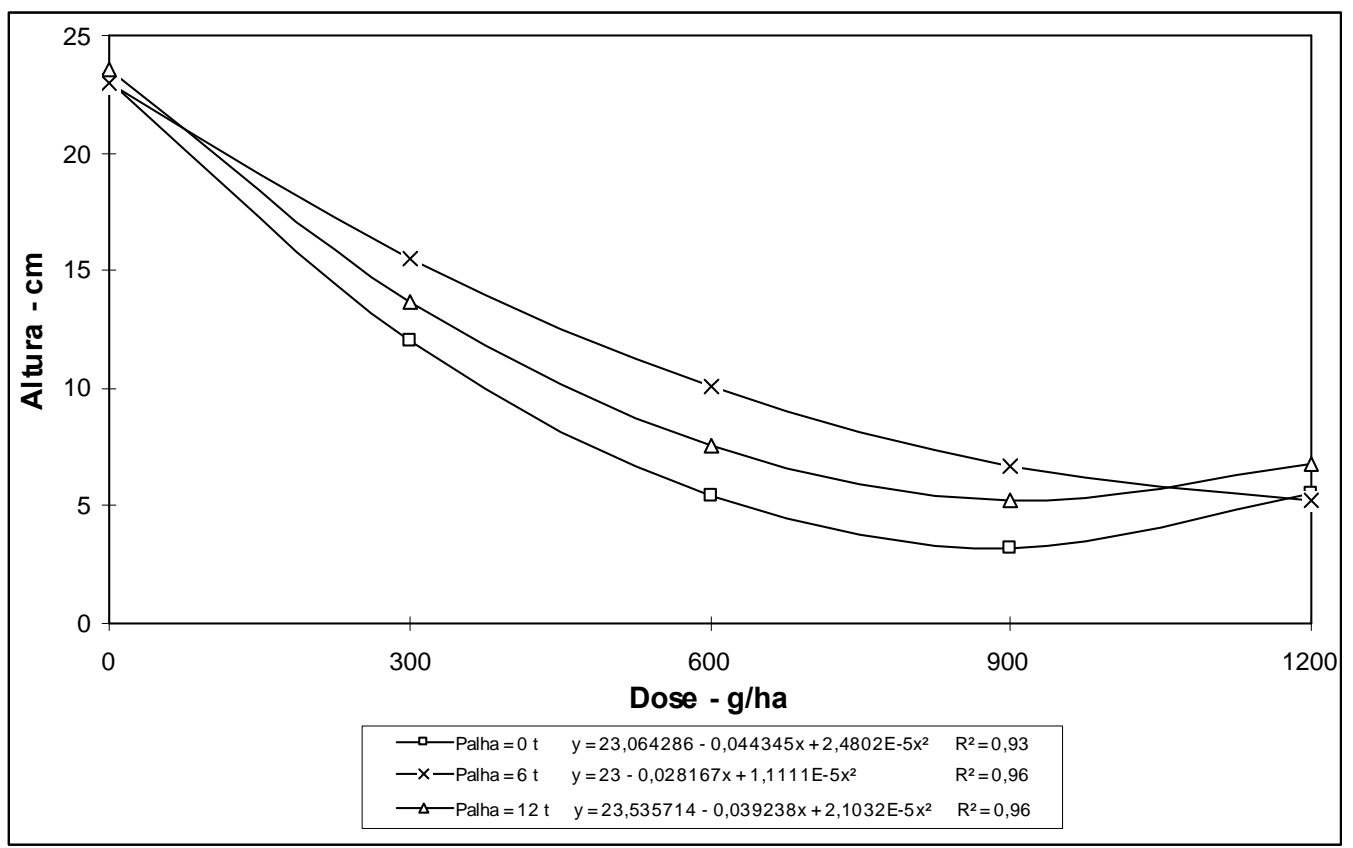

FIGURA 11. Influência da quantidade de palha e da dose de sulfentrazone na altura do sorgo aos 20 dias após a semeadura, em solo retirado na profundidade de 5 a $10 \mathrm{~cm}$, depois da irrigação.

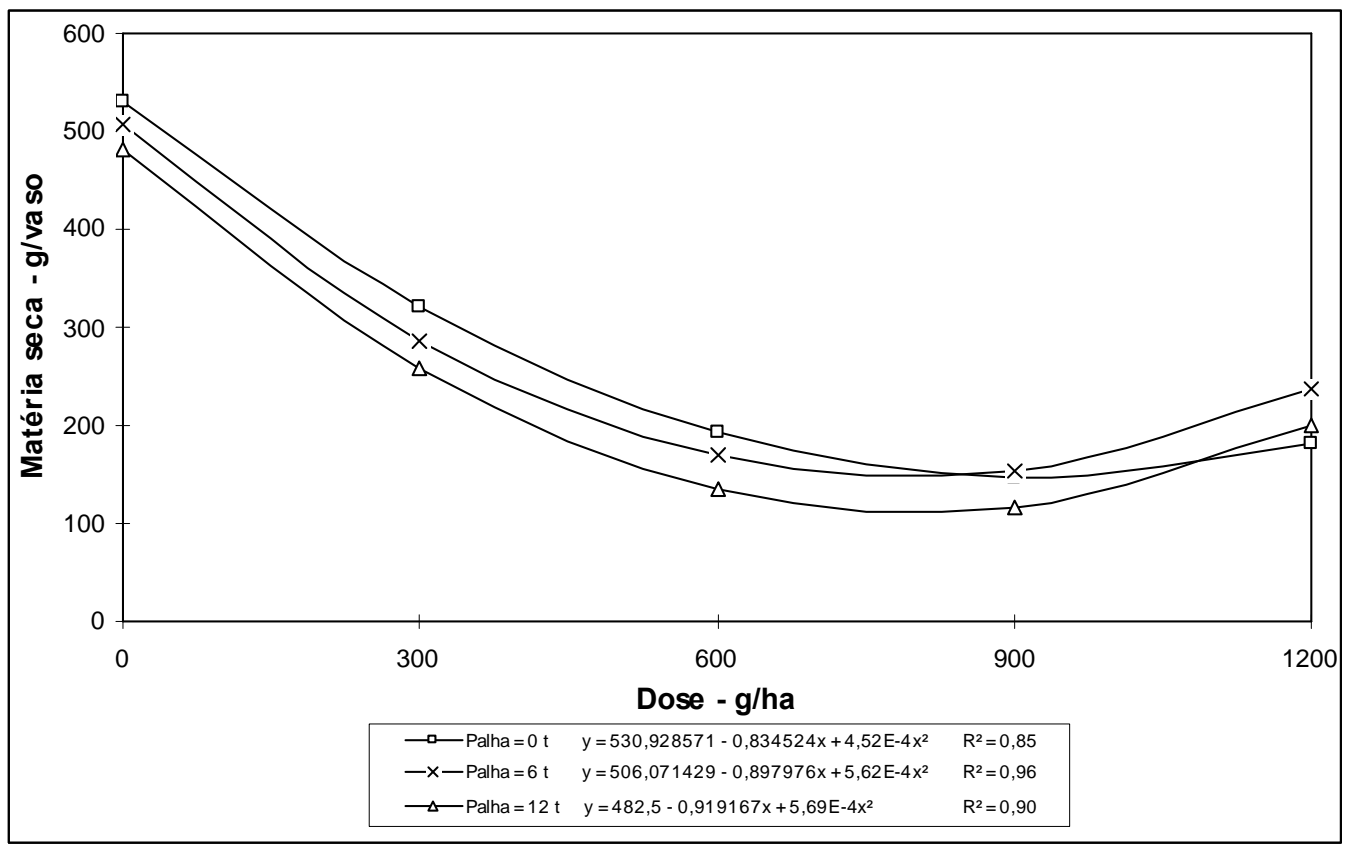

FIGURA 12. Influência da quantidade de palha e da dose de sulfentrazone na produção de matéria seca da parte aérea do sorgo forrageiro aos 20 dias após a semeadura, em solo retirado na profundidade de 0 a $5 \mathrm{~cm}$, depois da irrigação. 


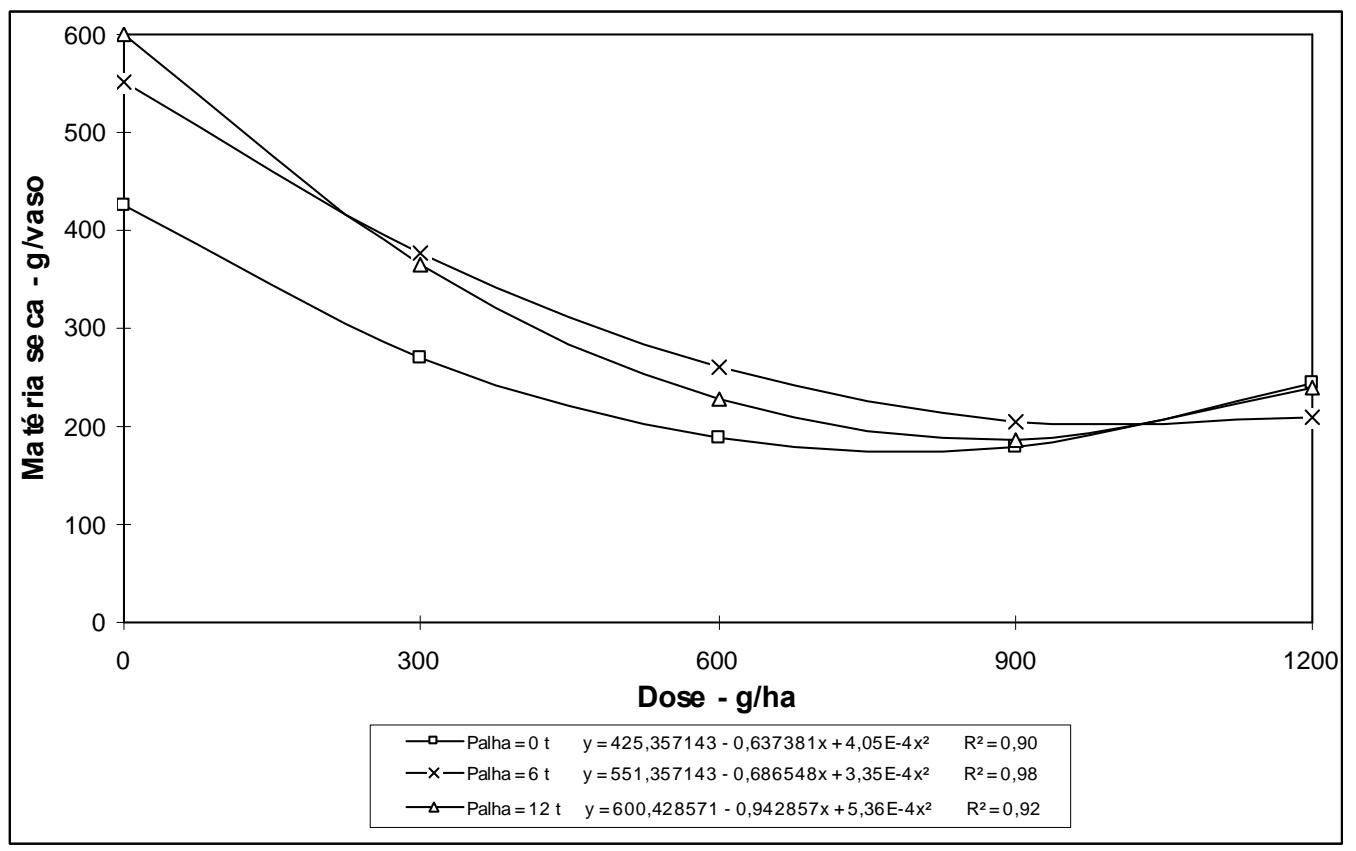

FIGURA 13. Influência da quantidade de palha e da dose de sulfentrazone na produção de matéria seca da parte aérea do sorgo forrageiro aos 20 dias após a semeadura, em solo retirado na profundidade de 5 a $10 \mathrm{~cm}$, depois da irrigação.

Esse comportamento foi semelhante ao do imazaquin (Rodrigues et al, 1998) e do atrazine (Fornarolli, 1997), mas diferente daquele observado com trifluralin por Rodrigues et al , 1997) .

Nas análises cromatográficas de solo, observou-se que, antes da irrigação, apenas em solo descoberto e na profundidade de $0-5 \mathrm{~cm}$, foi detectada a presença do sulfentrazone (Figura 14), sendo encontrados apenas traços do herbicida na profundidade de 5-10 cm (Figura 15). Supondo-se que o produto teria ficado retido na palha, a exemplo do que supunham Rodrigues et al (1997) com trifluralin, analisou-se também a palha, não sendo detectada a presença do sulfentrazone na cobertura morta em nenhum dos tratamentos, nem antes nem após a irrigação (Figuras 16 e 17). Isso pode ter ocorrido devido a: 1) interação do produto com a palha; 2) degradação do produto na palha; 3) formação de metabólitos na palha; 4) combinação entre esses fatores. É importante salientar que a metodologia utilizada na extração do sulfentrazone foi perfeitamente adequada ao trabalho, uma vez que o teste efetuado com o padrão analítico acusou 92,09 \% de recuperação em amostras de palha fortificadas, procedimento este rotineiro neste tipo de trabalho.

Analisando-se o solo após a irrigação, observou-se que os teores de sulfentrazone obtidos na profundidade de $5-10 \mathrm{~cm}$, foram semelhantes àqueles observados entre $0-5 \mathrm{~cm}$ (Figuras 18 e 19) em condições de solo coberto; em solo descoberto, no entanto, os teores encontrados na profundidade de $5-10 \mathrm{~cm}$, foram maiores do que os encontrados entre $0-5 \mathrm{~cm}$. Isso demonstra que a quantidade de chuva aplicada $(20 \mathrm{~mm})$, foi suficiente para lixiviar o produto para profundidades maiores.

Pelos resultados obtidos, nota-se que, mesmo ficando apenas traços no solo do total do sulfentrazone aplicado, essa quantidade foi suficiente para controlar satisfatoriamente a $B$. plantaginea no campo e causar nítidos sintomas de toxicidade na soja no campo e no sorgo forrageiro nos bioensaios. Presume-se que o 
produto, registrado e recomendado para a cultura da soja, por ser relativamente solúvel (490ppm conforme Rodrigues \& Almeida, 1998), foi lixiviado para camadas inferiores do solo com a chuva de $20 \mathrm{~mm}$ aplicada 24 horas após aplicação do herbicida, não sendo detectado pelas análises cromatográficas de solo realizadas.

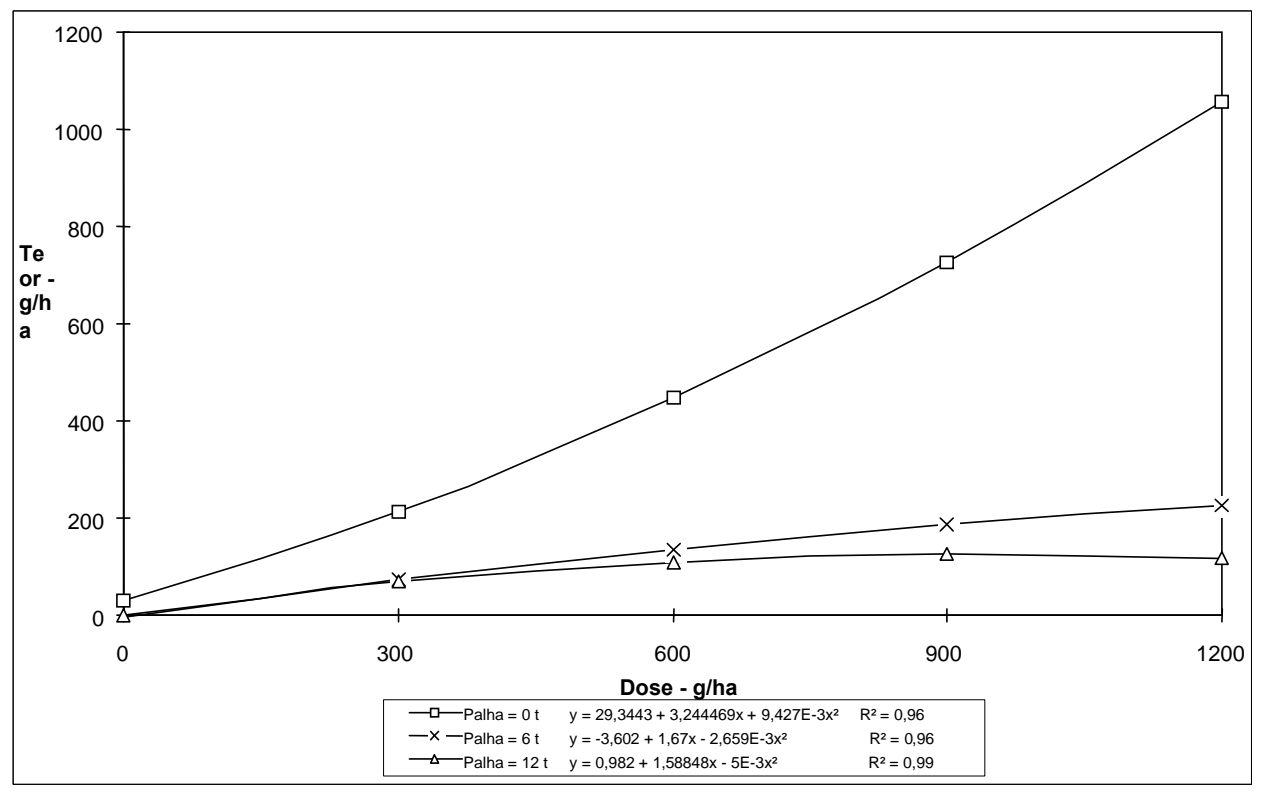

FIGURA 14. Influência da quantidade de palha e da dose de sulfentrazone no teor deste produto encontrado no solo na profundidade de 0 a $5 \mathrm{~cm}$, antes da irrigação.

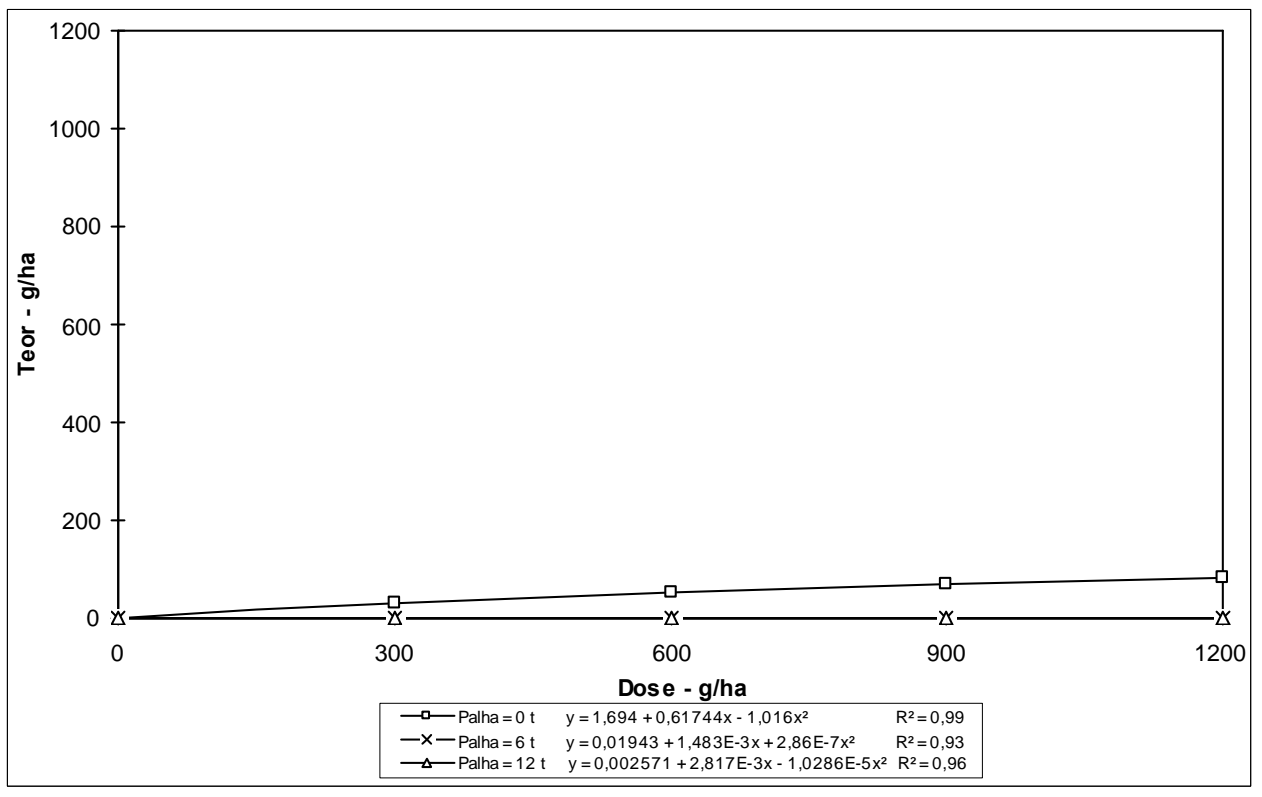

FIGURA 15. Influência da quantidade de palha e da dose de sulfentrazone no teor deste produto encontrado no solo na profundidade de 5 a $10 \mathrm{~cm}$, antes da irrigação. 


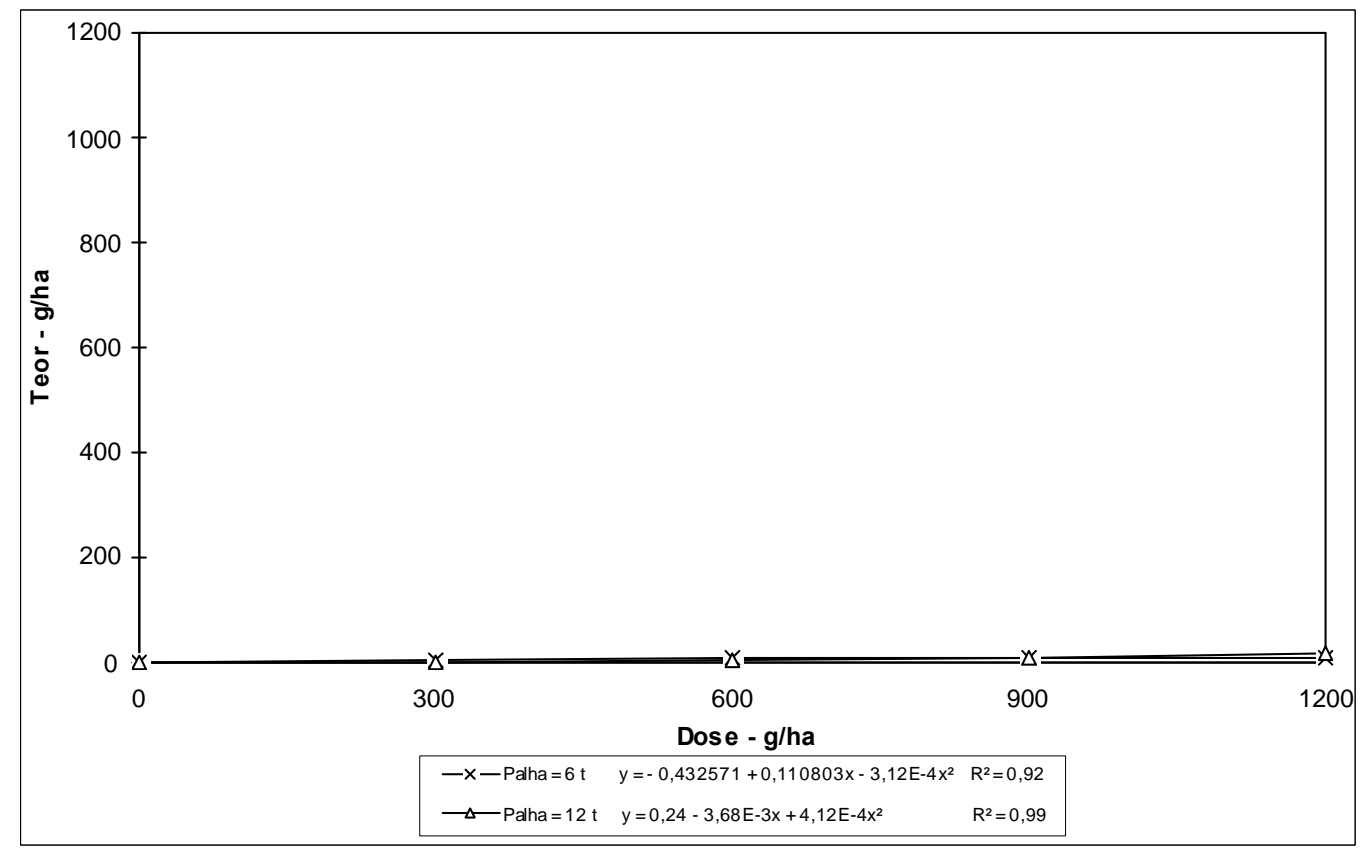

FIGURA 16. Influência da quantidade de palha e da dose de sulfentrazone no teor deste produto encontrado na palha de aveia, antes da irrigação.

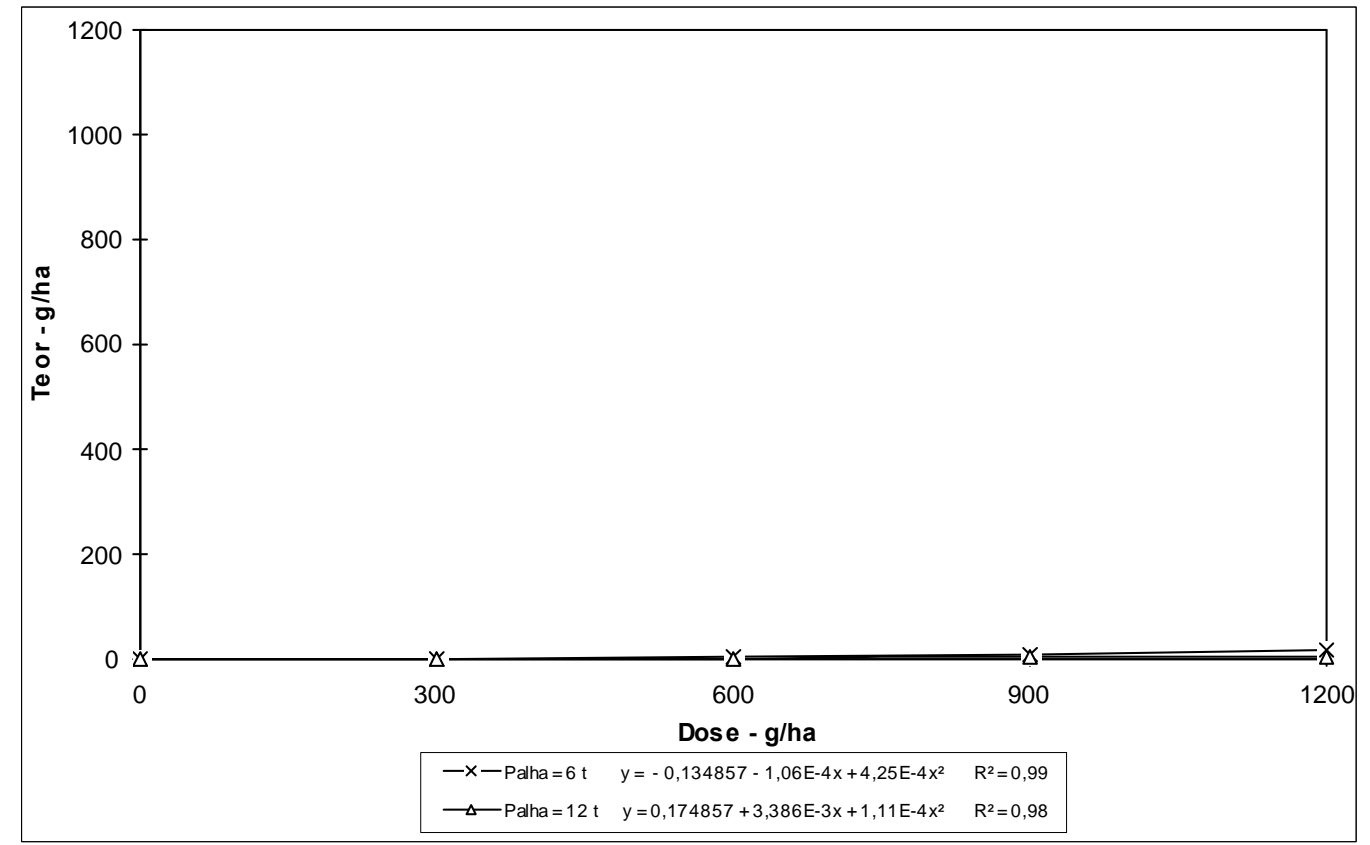

FIGURA 17. Influência da quantidade de palha e da dose de sulfentrazone no teor deste produto encontrado na palha de aveia, depois da irrigação. 


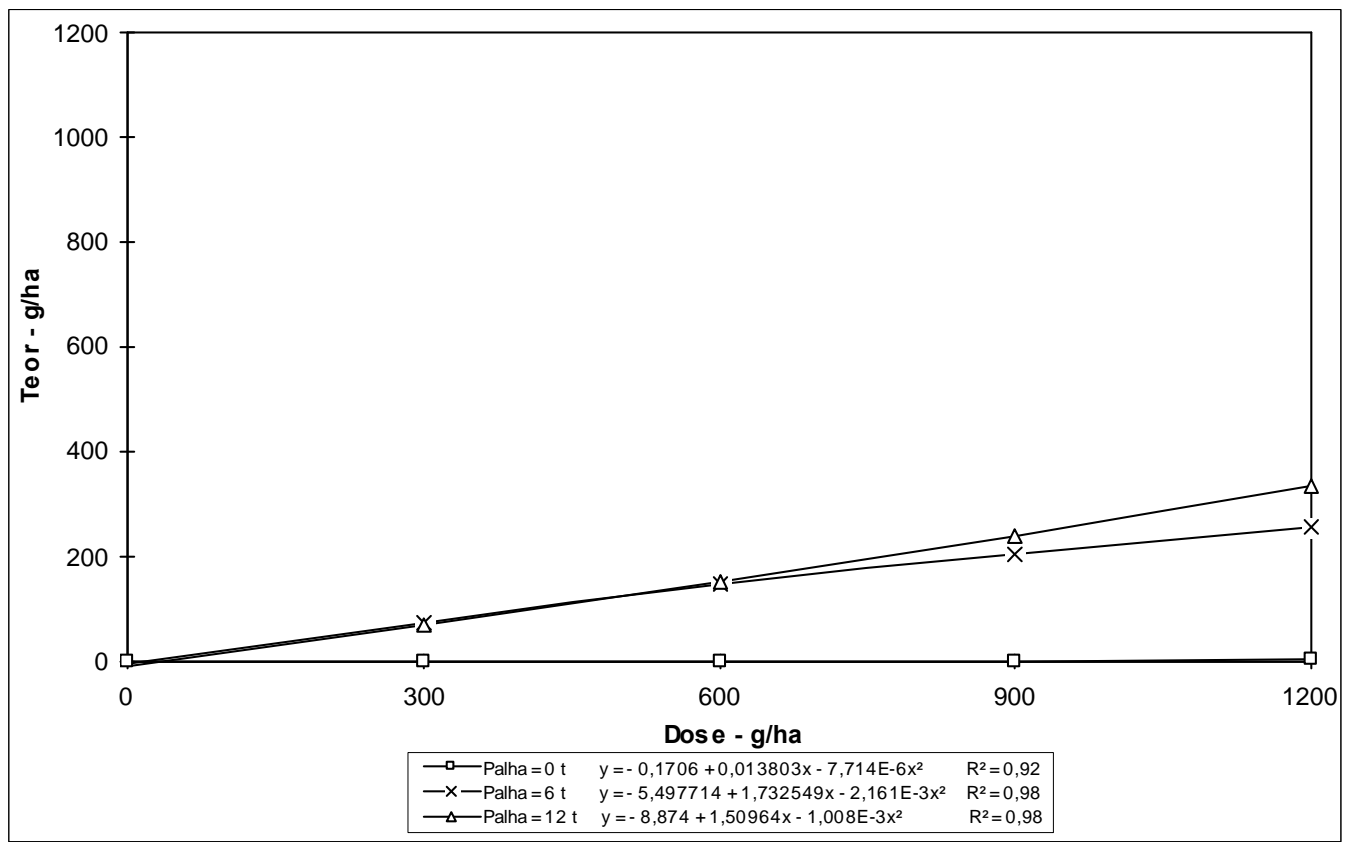

FIGURA 18. Influência da quantidade de palha e da dose de sulfentrazone no teor deste produto encontrado no solo na profundidade de 0 a $5 \mathrm{~cm}$, depois da irrigação.

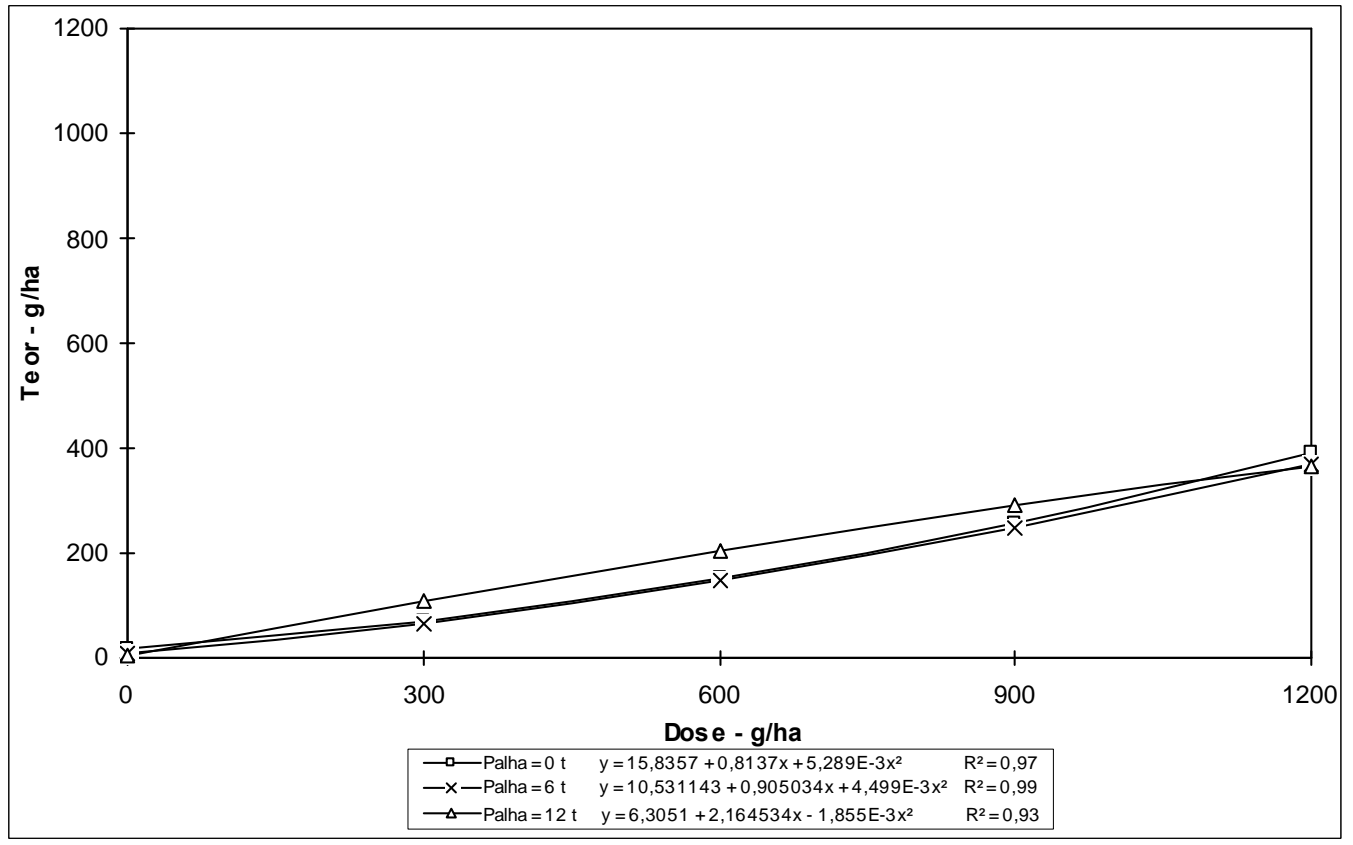

FIGURA 19. Influência da quantidade de palha e da dose de sulfentrazone no teor deste produto encontrado no solo na profundidade de 5 a $10 \mathrm{~cm}$, depois da irrigação. 


\section{LITERATURA CITADA}

ALMEIDA, F.S. A alelopatia e as plantas. Londrina, IAPAR, 1988. 60 p. (Circular IAPAR, 53).

BANKS, P.A. \& ROBINSON, E.L. The influence of straw mulch on the soil reception and persistence of metribuzin. Weed Sci., Champaign, v.30, n.2, p.164-8. 1982.

BANKS, P.A. \& ROBINSON, E.L. The fate of oryzalin applied to straw-mulched and nonmulched soils. Weed Sci., Champaign, v.32, p.269-272, 1984.

BANKS, P.A. \& ROBINSON, E.L. Soil reception and activity of acetochlor, alachlor and metolachlor as affected by wheat (Triticum aestivum), atraw irrigation. Weed Sci., Champaign, v.34, p.607-611, 1986.

FORNAROLLI, D.A. Influência da cobertura morta no comportamento do herbicida atrazine. UEL-Londrina, PR, 1997. Dissertação de Mestrado.

RODRIGUES, B.N. Influência da cobertura morta no comportamento dos herbicidas imazaquin e clomazone. Planta Daninha, v.11, n.1 e 2, p.21-8, 1993.

RODRIGUES, B.N. \& ALMEIDA, F.S. Guia de Herbicidas. 4ed. Londrina, PR, Ed. dos autores, 1998. 648p.
RODRIGUES, B.N. \& ALMEIDA, F.S. Influência da cobertura morta no comportamento dos herbicidas atrazine e metolachlor no sistema de plantio direto. In: FUNDAÇÃO INSTITUTO AGRONÔMICO DO PARANÁ, Londrina, PR. Resultados de pesquisa da Área de Herbologia, safras 1984/85 e 1985/86. Londrina, 1986. (Mimeografado).

RODRIGUES, B.N.; LIMA, J; FORNAROLLI, D.A. Aplicação de trifluralin em préemergência, sobre diferentes quantidades de cobertura morta, no sistema de plantio direto.In: CONGRESSO BRASILEIRO DA CIÊNCIA DAS PLANTAS DANINHAS, 21, Caxambu, MG, 1997. Resumos... Viçosa, SBCPD, p. 365.

RODRIGUES, B.N.; LIMA, J.; YADA, I.F.U.; FORNAROLLI, D.A.; Influência da cobertura morta na matocompetição e no comportamento do imazaquin em plantio direto de soja. PESQUISA AGROPECUÁRIA BRASILEIRA - PAB1998 NO PRELO.

STREK, H.J. \& WEBER, J.B. Adsorption, mobility and activity comparisons between alachlor (Lasso) and metolachlor (Dual). Proc. South. Weed Sci. Soc., 35:332-8, 1982.

THIER, H.P. \& ZEUMER, H. ed. Man. Pestic. Residue Anal., v.1, p.383-400, 1987. 